\title{
Multilevel Analysis: Village Does Not Have Contextual Effect on Hepatitis A Outbreak in Pacitan, East Java, Indonesia
}

\author{
Sugeng Retyono'), Setyo Sri Rahardjo²), Bhisma Murti3) \\ ${ }^{1)}$ Masters Program in Public Health, Universitas Sebelas Maret \\ 2)Faculty of Medicine, Universitas Sebelas Maret
}

\section{ABSTRACT}

Background: Hepatitis A virus infection (HAV) has generated about half of the total infection of hepatitis in the world. Poor environmental sanitation and unhealthy behavior of the society can increase the risk of Hepatitis A transmission. This study aimed to analyze the contextual effect of the village on biopsychosocial determinants of Hepatitis A.

Subjects and Method: This was an analytic observational study with a case-control approach. This study was conducted from January to February 2020. This study used fixed disease sampling. The sample of this study was 200 patients consisted of 50 Hepatitis A patients and 150 non-Hepatitis A patients in villages in Pacitan Regency. The dependent variable was Hepatitis A. The independent variables were age, education, income, history of Hepatitis A vaccination, handwashing behavior, food consumption, availability of clean water, and availability of latrines. This study used questionnaires to collect the data. The data were analyzed by multilevel multiple logistic regression using Stata 13.

Results: The risk of Hepatitis A infection decreased with age $\geq 40$ years $(\mathrm{OR}=0.06 ; 95 \%$ $\mathrm{CI}=0.01$ to $0.27 ; \mathrm{p}<0.001$ ), high education $(\mathrm{OR}=0.15 ; 95 \% \mathrm{CI}=0.03$ to $0.72 ; \mathrm{p}=0.018)$, high income $(\mathrm{OR}=0.14 ; 95 \% \mathrm{CI}=0.03$ to 0.77 ; $\mathrm{p}=0.023$ ), and history of Hepatitis A vaccina- tion $(\mathrm{OR}=0.07 ; 95 \% \mathrm{CI}=0.01$ to $0.84 ; \mathrm{p}=$ o.036). The risk of Hepatitis A infection increased with poor hand washing behavior $(\mathrm{OR}=5.27 ; 95 \% \mathrm{CI}=1.32$ to $21.03 ; \mathrm{p}=0.019)$, unhygienic food consumption $(\mathrm{OR}=9.67 ; 95 \%$ $\mathrm{CI}=2.41$ to $38.76 ; \mathrm{p}=0.001$ ), poor clean water availability $(\mathrm{OR}=22.64 ; 95 \% \mathrm{CI}=5.49$ to 93.35 ; $\mathrm{p}<0.001)$, and poor latrine $(\mathrm{OR}=4.78$; $95 \% \mathrm{CI}=$ 1.42 to $16.07 ; \mathrm{p}=0.012$ ). Village did not have level a contextual effect on Hepatitis A infection with intra-class correlation $<1 \%$.

Conclusion: The risk of Hepatitis A infection decreases with age $\geq 40$ years, high education, high income, and history of Hepatitis A vaccination. It increases with poor hand washing behavior, unhygienic food consumption, poor clean water availability, and poor latrine. Village does not have level a contextual effect on Hepatitis A.

Keywords: Hepatitis A, vaccine, contextual effect, multilevel analysis

\section{Correspondence: \\ Sugeng Retyono. Masters Program in Public Health, Universitas Sebelas Maret. Jl. Ir. Sutami 36A, Surakarta 57126, Central Java, Indonesia. Email: sugengretyono@gmail.com. Mobile: +6287758732030 .}

\section{Cite this as:}

Retyono S, Rahardjo SS, Murti B (2020). Multilevel Analysis: Village Does Not Have Contextual Effect on Hepatitis A Outbreak in Pacitan, East Java, Indonesia. J Epidemiol Public Health. 05(02): 195-206. https://doi.org/10.26911/jepublichealth.2020.05.02.07.

(c) (i) (2) Journal of Epidemiology and Public Health is licensed under a Creative Commons EY NC SA Attribution-NonCommercial-ShareAlike 4.0 International License.

\section{BACKGROUND}

Hepatitis A Virus Infection generates half of the total hepatitis infections in the world. More than 1.4 million new cases of Hepatitis A occurs annually (WHO, 2012). Hepa- titis A transmission is affected by personal hygiene and sanitation condition, highincome areas have fewer HAV cases than low-income areas (Sabbahi, 2017). Poor environmental sanitation and unhygienic 
eating habit can cause HAV transmission (Fares, 2015). HAV does not cause high mortality rate, however, it generates a negative impact on socio-economic, the emergence of various public health problems, and outbreaks (Pusdati,2014).

The result of Riskesdas (Basic Health Research) in 2007 and 2013 showed the increment of the proportion of hepatitis in Indonesia due to $\mathrm{HAV}, \mathrm{HBV}, \mathrm{HCV}$ and $\mathrm{HEV}$ infections from $0.6 \%$ to $1.2 \%$. In 2015, there were 78 cases of hepatitis A occurred in three regencies in East Java namely; Probolinggo, Lamongan, and Jember (Dinkes East Java Province, 2015).

Health Office of Pacitan Regency reported 1,257 cases of Hepatitis A outbreak in Pacitan Regency from June to August 2019 (Dinkes Kabupaten Pacitan, 2019). Poor environmental sanitation and unhealthy behavior were suspected to be the cause of Hepatitis outbreak.

Hepatitis A transmission is affected by some factors. According to Laila et al. (2019), an individual who washed hands without using soap after defecating had 7.90 times risk of having Hepatitis A infection compared to an individual who used soap. An individual who used contaminated water had 1.29 times risk of having Hepatitis A compared to an individual who used clean water standard (Sari et al., 2018).

Consuming unhygienic food got 17.1 times risk of having Hepatitis A (Kurup et al., 2019). The safe way to prevent hepatitis A transmssion is by cooking the food until done (Kemenkes, 2015).

Based on a study conducted by Harabandi et al. (2018), the use of latrine which did not meet the requirements increased the risk of getting hepatitis A infection.

The use of vaccine also affects HAV transmission (Alberts et al., 2019).

Other determinants that affect hepatitis $\mathrm{A}$ are income and education. Alberts et al. (2019) stated that a group of $<24$ years was 2.86 times at risk of having hepatitis A infection compared to a group of $\geq 45$ years.

Education has an important role to decrease Hepatitis A infection. Individuals with higher education get more information about healthy life and behavior. A group with low-education background had 1.82 times risk of having Hepatitis A (Mantovani et al., 2015). Economic status also affects Hepatitis A incidences (Sari et al., 2018; Arina et al., 2018).

This study aimed to analyze the contextual effect of the village on biopsychosocial determinants of Hepatitis A.

\section{SUBJECTS AND METHOD}

\section{Study Design}

This was a case control study conducted in Pacitan Regency, East Java, Indonesia, from January to February 2020.

\section{Population and Sample}

The population of this study was inpatients at Puskesmas (Community Health CenterS) in Pacitan, East Java, from June to August 2019. A sample of 50 Hepatitis A patients and 150 non-Hepatitis A patients was selected by fixed disease sampling.

\section{Study Variables}

The dependent variable was Hepatitis A. The independent variables were age, family income, education level, history of Hepatitis A vaccination, hand washing behavior, food consumption, availability of clean water, and availability of latrines.

\section{Operational Definition of Variables}

Hepatitis A was the individual's condition who experienced symptoms such as fever, headache, decreased appetite, nausea, vomiting, dark urine, and yellowing of the whites of the eyes. The result of test of blood samples showed HAV positive infection. The measurement scale was categorical. 
Age was the age of the study subjects at the time of the study. The measurement scale of continous and transformed into dichotomous.

Family Income was the overall average of income from husband, wife, and family members which was obtained from the last six-month income. The measurement scale was continous and transformed into dichotomous.

Education was the last level of education of the study subjects proven with a valid graduation certificate. The measurement scale was categorical.

History of Hepatitis A vaccination was the status of Hepatitis A vaccination. The measurement scale was categorical.

Food consumption was the behavior of study subjects in consuming food and beverages. The measurement scale was categorical.

Handwashing behavior was the washing hand behavior conducted by the study subjects before and after eating and after defecating. The measurement scale was categorical.

The availability of clean water was the clean water used by the study subjects for drinking and cooking. The measurement scale was categorical

The availibility of latrine was the type and condition of latrines used by study subjects. The measurement scale was categorical.

The active alert village was the village where the population had the readiness of resources, ability, willingness to prevent and overcome health problems, disaster, and emergency problems. The measurement scale was categorical.

\section{The instrument of the study}

This study used questionnaires which had been tested its valdity and reliability as the study instrument to collect data. The questionnaire was used to obtain data on age, family income, education level, history of Hepatitis A vaccination, hand washing behavior, food consumption, availability of clean water, and availability of latrines.

\section{Data Analysis}

Univariate analysis was used to determine frequency distributions and percentage characteristics of the study subjects. Bivariate analysis was used to examine the correlation between Hepatitis A with independent variables using chi-square test and odd ratio calculation with $95 \%$ confidence level. Multivariate analysis used a multilevel multiple logistic regression analysis to examine the contextual effect of villages toward hepatitis A infection.

\section{Research Ethics}

The Ethical clearance in this study was issued by the Health Research Ethics Committee of Dr. Moewardi Hospital, Surakarta, Indonesia, No. 1.399/XII/ HREC/2019, December 21 2019 .

\section{RESULTS}

\section{Sample Characteristics}

The characteristics of this study included age, gender, education, income and village level. Tables 1 and 2 shows sample characteristics.

Table 1. Sample characteristics (continous data)

\begin{tabular}{lccccc}
\hline \multicolumn{1}{c}{ Variable } & N & Mean & SD & Min. & Max. \\
\hline Age (year) & 200 & 42.07 & 14.8 & 15 & 87 \\
Income (rupiah) & 200 & $2,016,500$ & $1,072,288$ & 500,000 & $8,000,000$ \\
\hline
\end{tabular}

Table 1 shows the average age (year) of sample was 42.07 (Mean $=42.07 ; \mathrm{SD}=$ 14.8). The youngest age was 15 years and the oldest was 87 years. The average income was $\mathrm{Rp} 2,016,500$ per month $($ Mean $=2,016,500 ; \mathrm{SD}=1,072,288)$. The 
Retyono et al./ Village Does Not Have Contextual Effect on Hepatitis A Outbreak

lowest income was $\operatorname{Rp} 500,000$ and the highest was Rp 8,000,000.

Table 2. Sample characteristics (categorical data)

\begin{tabular}{|c|c|c|}
\hline Sample Characteristics & $\mathbf{N}$ & $\%$ \\
\hline \multicolumn{3}{|l|}{ Age (year) } \\
\hline$<40$ years & 105 & 52.50 \\
\hline$\geq 40$ years & 95 & $47 \cdot 50$ \\
\hline \multicolumn{3}{|l|}{ Gender } \\
\hline Female & 102 & 51.00 \\
\hline Male & 98 & 49.00 \\
\hline \multicolumn{3}{|l|}{ Education } \\
\hline Uneducated & 4 & 2.00 \\
\hline Unfinished Elementary School & 7 & 3.50 \\
\hline Elementary School & 36 & 18.00 \\
\hline Junior High School & 31 & $15 \cdot 50$ \\
\hline Senior High School & 112 & 56.00 \\
\hline Diploma & 4 & 2.00 \\
\hline Bachelor & 6 & 3.00 \\
\hline \multicolumn{3}{|l|}{ Income (Rupiah/ month) } \\
\hline$<\operatorname{Rp} 1,763,270$ & 87 & 43.50 \\
\hline$\geq \operatorname{Rp} 1,763,270$ & 113 & 56.50 \\
\hline \multicolumn{3}{|l|}{ Village Level } \\
\hline First Grade & 3 & 12.00 \\
\hline Second Grade & 8 & 32.00 \\
\hline Third Grade & 9 & 36.00 \\
\hline Ultimate Grade & 5 & 20.00 \\
\hline
\end{tabular}

Table 2 shows the majority of the study subjects aged <40 years (52.50\%), female (51\%), senior high school (56\%), monthly income average $\geq$ regencies minimum wage $(56,5 \%)$ and full alert village (36\%).

\section{Bivariate Analysis}

Bivariate analyis was used to determine the effect of independent variables toward the dependent variable using chi-squared test. Table 3 shows bivariate analysis.

Table 3 shows that the risk of Hepatitis A infection increased with poor behavior of washing hands $(\mathrm{OR}=7.84 ; 95 \% \mathrm{CI}=$ 3.85 to 15.96 ; $\mathrm{p}<0.001$ ), never get Hepatitis A vaccination $(\mathrm{OR}=2.14 ; 95 \% \mathrm{CI}=0.60$ to $7.58 ; \mathrm{p}=0.231$ ), unhygienic food consumption $(\mathrm{OR}=10.03 ; 95 \% \mathrm{CI}=4.74$ to 21.21; p <0.001), poor clean water availability $(\mathrm{OR}=12.16 ; 95 \% \mathrm{CI}=5.69$ to $25.99 ; \mathrm{p}$ $<0.001)$, poor latrine $(\mathrm{OR}=8.14 ; 95 \% \mathrm{CI}=$ 3.88 to $17.07 ; \mathrm{p}<0.001$ ).
Hepatitis A decreased with age 40 years $(\mathrm{OR}=0.37 ; 95 \% \mathrm{CI}=0.19$ to $0.74 ; \mathrm{p}=$ o.004), education $\geq$ Senior high school $(\mathrm{OR}=0.10 ; 95 \% \mathrm{CI}=0.05$ to $0.74 ; \mathrm{p}$ $<0.001)$, and high income $(\mathrm{OR}=0.07 ; 95 \%$ $\mathrm{CI}=0.03$ to $0.16 ; \mathrm{p}<0.001$ ).

\section{Multivariate Analysis}

Table 4 showed the results of a multilevel multiple logistic regression analysis.

Table 4 demonstrates the effect of age toward Hepatitis A incidences. An individual aged $\geq 40$ years had 0.06 times risk of having Hepatitis A infection compared to an individual aged $<40$ years $(\mathrm{OR}=0.06$; 95\% $\mathrm{CI}=0.01$ to 0.27 ; $<<0.001)$.

There was an effect of education level on the incidence of Hepatitis A. Individual with the high-education level was 0.15 times at risk to get Hepatitis A infection compared to those with low education $(\mathrm{OR}=0.15 ; 95 \% \mathrm{CI}=0.03$ to $0.72 ; \mathrm{p}=0.018)$. 
Retyono et al./ Village Does Not Have Contextual Effect on Hepatitis A Outbreak

There was an effect of family income on Hepatitis A incidences. An individual with a high family income had 0.14 times risk of having Hepatitis A compared to an individual with low family income (OR= $0.14 ; 95 \% \mathrm{CI}=0.03$ to $0.77 ; \mathrm{p}=0.023)$.

The history of Hepatitis A vaccination gave an effect on Hepatitis A incidences. An individual who got Hepatitis A vaccine had 0.07 times risk to have Hepatitis A infection
$(\mathrm{OR}=0.07 ; 95 \% \mathrm{CI}=0.01$ to $0.84 ; \mathrm{p}=$ o.036).

There was an effect of washing hands behavior on Hepatitis A incidences. An individual who had poor behavior of washing hands had 5.27 times risk of having Hepatitis A compared to an individual who had good handwashing behavior $(\mathrm{OR}=5.27$; 95\% $\mathrm{CI}=1.32$ to $21.03 ; \mathrm{p}=0.019)$.

Table 3. Bivariate Analysis on the determinants of Hepatitis A infection

\begin{tabular}{|c|c|c|c|c|c|c|c|c|c|}
\hline \multirow{3}{*}{$\begin{array}{c}\text { Independent } \\
\text { Variables }\end{array}$} & \multicolumn{4}{|c|}{ Hepatitis A } & \multirow{2}{*}{\multicolumn{2}{|c|}{ Total }} & \multirow{3}{*}{ OR } & \multirow{3}{*}{$95 \%$ CI } & \multirow{3}{*}{$\mathbf{p}$} \\
\hline & \multicolumn{2}{|c|}{ No } & \multicolumn{2}{|c|}{ Yes } & & & & & \\
\hline & $\mathbf{N}$ & $\%$ & $\mathbf{N}$ & $\%$ & $\mathbf{N}$ & $\%$ & & & \\
\hline \multicolumn{10}{|l|}{ Age } \\
\hline$<40$ years & 70 & 66.7 & 35 & $33 \cdot 3$ & 105 & 100 & \multirow[t]{2}{*}{0.37} & $0.19-$ & \multirow[t]{2}{*}{0.004} \\
\hline$\geq 40$ years & 80 & 84.2 & 15 & 15.8 & 95 & 100 & & 0.74 & \\
\hline \multicolumn{10}{|l|}{ Education } \\
\hline$<\mathrm{SHS}$ & 39 & 50 & 39 & 50 & 78 & 100 & \multirow[t]{2}{*}{0.10} & $0.05^{-}$ & \multirow[t]{2}{*}{$<0.001$} \\
\hline$\geq$ SHS & 111 & 91 & 11 & 9 & 122 & 100 & & 0.21 & \\
\hline \multicolumn{10}{|l|}{ Family Income } \\
\hline Low & 44 & 50.6 & 43 & 49.4 & 87 & 100 & \multirow[t]{3}{*}{0.07} & $0.03-$ & \multirow[t]{3}{*}{$<0.001$} \\
\hline High & 106 & 93.8 & 7 & 6.2 & 113 & 100 & & 0.16 & \\
\hline \multicolumn{8}{|l|}{ Hepatitis A } & & \\
\hline Vaccination & & & & & & & & & \multirow{3}{*}{0.231} \\
\hline Ever & 18 & $85 \cdot 7$ & 3 & 14.3 & 21 & 100 & \multirow[t]{2}{*}{2.14} & $0.60-$ & \\
\hline Never & 132 & $73 \cdot 7$ & 47 & 26.3 & 179 & 100 & & $7 \cdot 58$ & \\
\hline \multicolumn{10}{|l|}{ Washing Hands } \\
\hline Behavior & & & & & & & \multirow{3}{*}{7.84} & & \multirow{3}{*}{$<0.001$} \\
\hline Good & 118 & 88.1 & 16 & 11.9 & 134 & 100 & & $3.85^{-}$ & \\
\hline Poor & 32 & 48.5 & 34 & 51.5 & 66 & 100 & & $15 \cdot 96$ & \\
\hline \multicolumn{10}{|l|}{ Food } \\
\hline Consumption & & & & & & & \multirow{3}{*}{10.03} & & \multirow{3}{*}{$<0.001$} \\
\hline Hygienic & 114 & 90.5 & 12 & 9.5 & 126 & 100 & & $4.74-$ & \\
\hline Unhygienic & 36 & 48.6 & 38 & 51.4 & 74 & 100 & & 21.21 & \\
\hline \multicolumn{10}{|l|}{$\begin{array}{l}\text { The availibility } \\
\text { of clean water }\end{array}$} \\
\hline Adequate & 119 & 90.8 & 12 & 9.2 & 131 & 100 & \multirow[t]{2}{*}{12.16} & $5.69-$ & \multirow[t]{2}{*}{$<0.001$} \\
\hline Inadequate & 31 & 44.9 & 38 & 55.1 & 69 & 100 & & 25.99 & \\
\hline $\begin{array}{l}\text { The Availibility } \\
\text { of latrine }\end{array}$ & & & & & & & & & \\
\hline Adequate & 108 & 90 & 12 & 10 & 120 & 100 & 8.14 & $3.88-$ & $<0.001$ \\
\hline Inadequate & 42 & 52.5 & 38 & 47.5 & 80 & 100 & & 17.07 & \\
\hline
\end{tabular}

There was an effect of food consumption on Hepatitis incidences. An individual who consumed unhygienic food was 9.67 times at risk of having Hepatitis A infection compared to an individual who consumed hygienic food $(\mathrm{OR}=9.67 ; 95 \% \mathrm{CI}=2.41$ to 38.76; $\mathrm{p}=0.001$ ).

There was an effect of the availability of clean water on Hepatitis A incidences. An individual who used non-standard of clean water had 22.64 times risk of having 
Hepatitis A compared to an individual who used clean water standard.

There was an effect of the availability of latrines on Hepatitis A incidences. An individual who used inadequate latrine was 4.78 times at risk of having Hepatitis infection compared to an individual who had adequate latrine $(\mathrm{OR}=4.78 ; 95 \% \mathrm{CI}=$ 1.42 to $16.07 ; \mathrm{p}=012$ ).

Table 4. Multilevel multiple logistic regression analysis on the determinants of Hepatitis A infection

\begin{tabular}{|c|c|c|c|c|}
\hline \multirow{2}{*}{ Independent Variables } & \multirow{2}{*}{ OR } & \multicolumn{2}{|c|}{$95 \% \mathrm{CI}$} & \multirow{2}{*}{$\mathbf{p}$} \\
\hline & & Lower Limit & Upper Limit & \\
\hline $\begin{array}{l}\text { Fixed Effect } \\
\text { Age } \\
\text { Education ( } \geq \text { Senior high school) } \\
\text { Income (High) } \\
\text { Hepatitis A vaccination (ever) } \\
\text { Washing hands behavior (poor) } \\
\text { Food consumption (unhygienic) } \\
\text { Invailibility of clean water } \\
\text { Inavailibility of latrine } \\
\text { Constant } \\
\text { Random Effect } \\
\text { Var (Konstanta) } \\
\text { N observation= } 200 \\
\text { N group= } 25 \\
\text { Log Likelihood= }-36.428797 \\
\text { p }<\text { o.oo1 } \\
\text { Intraclass Correlation }(\mathrm{ICC})<1 \%\end{array}$ & $\begin{array}{c}0.06 \\
0.15 \\
0.14 \\
0.07 \\
5.27 \\
9.67 \\
22.64 \\
4.78 \\
0.95\end{array}$ & $\begin{array}{l}0.01 \\
0.03 \\
0.03 \\
0.01 \\
1.32 \\
2.41 \\
5.49 \\
1.42 \\
0.08\end{array}$ & $\begin{array}{c}0.27 \\
0.72 \\
0.77 \\
0.84 \\
21.03 \\
38.76 \\
93.35 \\
16.07 \\
11.90\end{array}$ & $\begin{array}{c}<0.001 \\
0.018 \\
0.023 \\
0.036 \\
0.019 \\
0.001 \\
<0.001 \\
0.012 \\
0.972\end{array}$ \\
\hline
\end{tabular}

\section{DISCUSSION}

\section{The effect of age on Hepatitis $A$}

The result of this study showed that age affected Hepatitis A incidences. Age illustrated biological, psychological, and social maturity.

The result of this study is in line with a study conducted by Alberts et al. (2019) that there was a significant effect between age and Hepatitis A incidences $(\mathrm{aOR}=\mathbf{2 . 8 6}$; $95 \% \mathrm{CI}=1.98$ to 4.14 ). Group of $<24$ age was 2.86 times at risk of having Hepatitis A infection $(\mathrm{aOR}=2.86 ; 95 \% \mathrm{CI}=1.98$ to 4.14). Group of $<24$ had 2.86 times risk to get Hepatitis A infection compared to a group of $\geq 45$ years.
There was no contextual effect of the village on the variation of Hepatitis A cases (ICC $<1 \%$ ). It happened because most of the observed villages had the same characteristics and were categorized in the third grade of active alert Village with a total of 9 villages (36\%).
The result of a study conducted by Harabandi et al. (2018) presented the significant effect between age and Hepatitis A incidences $(\mathrm{OR}=7.22 ; 95 \% \mathrm{CI}=4.04$ to 12.93; $\mathrm{p}<0.001)$. Adult age group was 7.22 times at risk of having Hepatitis A compared to adolescent age group. The adult age group had a higher risk to get severe Hepatitis A infection (Zyl et al., 2019). This might occur because adul age group had weaker immune systems than adolescent age group

Based on the result of this study and the statements above, it can be concluded that age affects the incidences of Hepatitis A infection. 


\section{The effect of education on Hepa- titis A}

The result of this study indicated that education level affected Hepatitis A incidences. Clean and healthy living behavior was affected by formal education. An individual with a higher education level gets more information about clean and healthy living behavior (Bellido dan Arnedo, 2011)

This study is in line with a study conducted by Mantovani et al. (2015) that an individual with low-education level was 1.82 times at risk of having Hepatitis A compared to an individual with higher education level (OR=.82; 95\% CI= 0.99 to 3.33; $\mathrm{p}=0.053$ )

Kartika et al. (2019) stated that a child from a mother with a low-educational level had a possibility to get a risk of having diarrhea 1.60 units greater than a child from a mother with a higher-educational level $(\mathrm{b}=1.60$; $95 \% \mathrm{CI}=0.37$ to $2.83 ; \mathrm{p}=$ o.011). Hepatitis A was more likely to happen to groups with low educational levels (54.95\%) (Jemal, 2018). Formal education affected the attitude and behavior formation of an individual to understand, accept or reject the health information.

Based on the result of this study and the statements, it can be concluded that educational level affects the incidences of Hepatitis A.

\section{The effect of family income on Hepatitis A}

The result of this study showed that family income affected Hepatitis A incidences. The availability od a healthy home was fulfilled if an individual had adequate income.

The result of this study is in line with a study conducted by Sari et al. (2018), that there was a correlation between Hepatitis in Indonesia with Economy status $(\mathrm{OR}=$ 1.45 ; $95 \% \mathrm{CI}=1.15$ to 1.81 ; $\mathrm{p}=0.001$ ). Adequate income could fulfill family needs which could affect family happiness (Mock et al., 1993).

The result of this study is in line with a study by Mantovani et al. (2015), that an individual with low income was 2.03 times at risk of having Hepatitis A compared to an individual who had higher income $(\mathrm{OR}=$ 2.03 ; $95 \% \mathrm{CI}=1.10$ to 3.72 ; $\mathrm{p}=0.023$ ). Adequate family income could enable an individual to fulfill family needs including adequate health facilities to get a proper life.

Based on the result of the study and the statements, it can be concluded that family income affects Hepatitis A incidence.

\section{The effect of Hepatitis A vaccina- tion on Hepatitis A}

The result of this study showed that history of Hepatitis A vaccination affected Hepatitis A incidences. Age group of over 40 had higher immune response than age group of under 40 (Link-Gelles, et al., 2018).

The result of this study is in line with a study conducted by Lawler (2017) that an individual who got Hepatitis A vaccination had a possibility (logodd) of not having Hepatitis A 2.11 units greater than an individual who did not get Hepatitis A vaccination.

Based on the result of a study conducted by Alberts et al. (2019), there was a significant effect between Hepatitis A vaccination and Hepatitis A incidence $(\mathrm{aOR}=$ 2.00; $95 \% \mathrm{CI}=1.33$ to 3.03 ). An individual who did not get Hepatitis A vaccination was 2.0o times at risk of having Hepatitis A infection compared to an individual who got the vaccination. The distribution of Hepatitis A vaccine to a risk group might become the alternative to decrease Hepatitis A incidences. Pharmaceutical installation in every regency should provide Hepatitis A vaccine.

Based on the result of the study and the statements above, it can be concluded 
that Hepatitis A vaccination have an effect on Hepatitis A incidences.

\section{The effect of hand washing beha- vior on Hepatitis $A$}

The result of this study indicated that handwashing behavior affected Hepatitis A incidences. Microorganisms could last for 60 minutes on the surface of the palms, washing hands with soap and running water could prevent the transmission of disease (Mandli et al., 2017).

The result of this study is supported by a study conducted by Laila et al. (2019) that an individual did not who washed hands without using soap had 7.90 times risk of having Hepatitis A compared to an individual who washed hands using soap $(\mathrm{OR}=7.90 ; 95 \% \mathrm{CI}=3.14$ to $19.88 ; \mathrm{p}$ $<0.001)$.

According to a study conducted by Ramadani et al. (2019), an individual who had poor handwashing behavior might experience diarrhea 1.34 units greater than an individual with good handwashing behavior $(\mathrm{b}=1.34$; $95 \% \mathrm{CI}=0.12$ to $2.40 ; \mathrm{p}=$ o.030). The habit of handwashing with soap and running water could protect an individual from the possibility of germs entering the body.

Based on the result of the study and the statements, it can be concluded that handwashing behavior affects the Hepatitis A incidences.

\section{The effect of food consumption on hepatitis A}

The result of this study indicated that food consumption affected Hepatitis A incidence. Food contamination could occur through direct contact with products or through food handlers (Harabandi et al., 2018).

The result of this study is in line with a study conducted by Kurup et al. (2019) that an individual who consumed contaminated food was 17.1 times at risk of getting Hepatitis A infection compared to an individual who consumed hygienic food $(\mathrm{OR}=17.1 ; 95 \% \mathrm{CI}=3.8$ to 76.7$)$.

The result of this study is also in line with a study conducted by Viray et al. (2019), that the outbreak of Hepatitis A in Hawai in 2016 was (86\%) mostly caused by contaminated food. Contaminated food and improper food handling might generate HAV remained alive in the food and cause Hepatitis A infection.

Based on the result of this study and the statements above, it can be concluded that food consumption affected the incidence of Hepatitis A.

\section{The effect of the availability of clean water on Hepatitis A}

The result of this study showed that the availability of clean water affected Hepatitis A incidences. Clean water that met physical, microbiological, chemical and radioactive requirements was safe for consumption (Kemenkes, 2010b).

The result of this study is in line with a study conducted by Harabandi et al. (2018), that there was an individual who used non-standard clean water was 10.07 times at risk of having Hepatitis A compared to an individual who used standard clean water $(\mathrm{OR}=10.07 ; 95 \% \mathrm{CI}=5.63$ to 18.01; $\mathrm{p}<0.001)$.

According to a study conducted by Mantovani et al. (2015), an individual who used unprocessed clean water had 8.17 times risk to get Hepatitis A compared to an individual who used processed clean water $(\mathrm{aOR}=8.17 ; 95 \% \mathrm{CI}=1.07$ to $62.53 ; \mathrm{p}=$ o.043). The weather might affect the availability of clean water so it was necessary to prepare a reservoir of clean water that meets health requirements.

Based on the result of this study and the statements, it can be concluded that the availability of clean water affects Hepatitis A incidence. 


\section{The effect of latrines on Hepatitis A}

The result of this study showed that the availability of latrines affected Hepatitis A incidences. Defecating carelessly was suspected to be the main cause of diarrhea and enteric parasite in the world (Patil et al., 2015).

The result of this study is in line with a study conducted by Harabandi et al. (2018) that the family who used nonstandardized latrine had 1.86 times risk to get Hepatitis A infection compared to the family who used adequate latrine $(\mathrm{OR}=$ 1.86; $95 \% \mathrm{CI}=1.02$ to $3.40 ; \mathrm{p}=0.04)$.

A study conducted by Aryana et al. (2014) stated that an individual who used inadequate latrine had 18 times risk to get Hepatitis A compared to an individual who used standard latrine $(\mathrm{OR}=18 ; 95 \% \mathrm{CI}=$ 4.38 to $74.01 ; \mathrm{p}<0.001)$. Defecation behavior might also be affected by the availability of latrines. A drought-prone area needed clean water supply so the community could use latrines.

Based on the result and statements above, it can be concluded that the availability of latrines gives effect toward Hepatitis A incidence.

\section{The Effect of Village on Hepatitis A Incidences}

The result of the study showed that there was no contextual effect of the village on the variation of Hepatitis A incidences (ICC $<1 \%)$. In constructing alert village needed availability and capability of the sources which must be prepared (Ministry of Health, 2010a). The development of alert village could be seen from the functioning of a disaster response system and a community-based surveillance system (Laksono and Sopacua, 2017).

The result of this study is in line with a study conducted by Harabandi et al. (2018), that there was no significant correlation between the location of residence with Hepatitis A incidences $(\mathrm{OR}=0.64$; CI95\% 0.36-1.15; $\mathrm{p}=0.14$ ).

The result of this study is supported by a study conducted by Putri et al. (2020), that the village level did not affect the incidences of Diabetes Mellitus type 2 (ICC= 1\%). There was no contextual effect of the village on the incidences of Hepatitis A. It might occur because most of the observed villages had lack variation of characteristics and were categorized in the third grade of the active alert village.

Based on the result and statements of the study, it could be concluded that the location of residence did not affect the incidences of any illnesses including Hepatitis A.

Based on this study, it can be concluded that there are a significant effects of ages, education, income, history of Hepatitis A vaccination, handwashing behavior, food consumption, the availability of clean water, and the availability latrines toward Hepatitis A incidences. The variation of the village does not show the contextual effect toward Hepatitis A incidences.

\section{AUTHOR CONTRIBUTION \\ Sugeng Retyono who had some responsi- bilities such as conducting the study, collecting the data of the study, formulating the article, and processing the data. Setyo Sri Rahardjo had responsibilities to orga- nize the background and discuss the study discussion. Bhisma Murti had roles in formulating the frameworks and analyzing the data of the study.}

\section{CONFLICT OF INTEREST}

There was no conflict of interest in this study.

\section{FUNDING AND SPONSORSHIP}

The fund of this study was from the Budget of Agency for Health Human Resources Development and Empowerment, Ministry 
of Health of the Republic of Indonesia, 2020.

\section{ACKNOWLEDGEMENT}

We give the best gratitude to the Head of Pacitan District Health Office and the head of the UPT. Puskesmas in Pacitan who allowed us to conduct the study. We also give gratitude to all inpatients who have been willing and cooperative to become the respondents of the study.

\section{REFERENCE}

Alberts CJ, Boyd A, Bruisten SM, Heijman T, Hogewoning A, Rooijen MV, Siedenburg E, Sonder GJB (2019). Hepatitis A incidence, seroprevalence, and vaccination decision among MSM in Amsterdam, the Netherlands. Vaccine, 37(21): 2849-2856. https:// doi:10.1016/j.vaccine.2019.03.048.

Arina CL, Rahardjo SS, Murti B (2018). Analysis of the contextual effect of village characteristics and other determinants of diarrhea in children under five, Banjarnegara, Central Java. jepublichealth, 03(03): 342-352. https://doi.og/10.26911/jepublichealth.2 018.03.03.05.

Aryana IGK, Putra IGNS, Karyana IPG (2014). Risk factors of hepatitis A outbreak in students at elementary schools, 79-84.

Bellido-Blasco J, Arnedo-Pena A (2011). Epidemiology of infectious diarrhea, Elsevier. 569-581. Available at: http: //www.sciencedirect.com/science/article/pii/B9780444522726006899.

Dinkes Kabupaten Pacitan (2019). Laporan KLB Hepatitis A Kabupaten Pacitan tahun 2019.

Dinkes Prov Jawa Timur (2015). Laporan KLB Hepatitis A Provinsi Jawa Timur tahun 2015.

Fares A (2015). Seasonality of hepatitis: A review update. J Family Med Prim Care, 4(1): 96-100. Retrieved from: https://doi.org/10.4103/2249-4863.152263.

Harabandi R, Odari EO, Lihana RW (2018). Prevalence of hepatitis A virus in patients attending a referral hospital in Bubanza Province, Northwest Burundi. Int J Res Med Sci, 7(1): 135140. https://doi.org/10.18203/23206012.ijrms20185368.

Jemal S (2018). Knowledge and practices of hand washing among health professionals in Dubti Referral Hospital, Dubti, Afar, Northeast Ethiopia. https://doi.org/10.1155/2018/5290797.

Kartika DS, Rahardjo SS, Murti B (2019). Multilevel analysis on the contextual effects of hygiene, environmental sanitation, and diarrhea prevention in elementary school students in Ngawi, East Java. jepublichealth, 4(2): 97108. https://doi.org/10.26911/jepublichealth.2019.04.02.05.

Kementerian Kesehatan (2010a). Keputusan Menteri Kesehatan Republik Indonesia Nomor 1529 Tahun 2010 Tentang Pedoman Umum Pengembangan Desa dan Kelurahan Siaga Aktif.

Kementerian Kesehatan (2010b). Peraturan Menteri Kesehatan Republik Indonesia Nomor 492 Tahun 2010 Tentang Persyaratan Kualitas Air Minum.

Kementerian Kesehatan (2015). Peraturan Menteri Kesehatan Republik Indonesia Nomor 53 Tahun 2015 Tentang Penanggulangan Hepatitis Virus.

Kurup KK, Manickam P, Gurav Y (2019). Infected food handlers led to an outbreak of hepatitis A in Ernakulam district, Kerala, Southern India, 2016. Clinical Epidemiology and Global Health. 8(1):308-312. https://doi.org/10.1016/j.cegh.2019.08.001. 
Laila NH, Mahkota R, Sariwati E, Setiabudi DA (2019). Faktor risiko terjadinya Kejadian Luar Biasa (KLB) Hepatitis A di Kabupaten Tangerang tahun 2016. Jurnal Epidemiologi Kesehatan Indonesia. 2(1): 1-6. https://doi.org/10.7454/epidkes.v2i1.3099.

Laksono AD, Sopacua E (2017). Review kebijakan pada indikator pengembangan desa siaga di Provinsi Jawa Timur policy review on the indicators of alert. JMPK, 12(4): 176-182.

Lawler EC (2017). Effectiveness of vaccination recommendations versus mandates: Evidence from the hepatitis A vaccine. jhealeco, 52: 45-62. https://doi: 10.1016/j.jhealeco.2017.-01.002.

Link-Gelles R, Hofmeister MG, Nelson NP (2018). Use of hepatitis A vaccine for post-exposure prophylaxis in individuals over 40 years of age: A systematic review of published studies and recommendations for vaccine use Vaccine, 36(20): 2745-2750. https: //doi:10.1016/j.vaccine.2018.04.015.

Mandli J, Attar A, Ennaji MM, Amine A (2017). Indirect competitive electrochemical immunosensor for hepatitis A virus antigen detection. J.jelechem, 799. https://doi:10.1016/j.jelechem. 2017.05.047.

Mantovani SAS, Delfino BM, Martins AC, Oliart-Guzmán H, Pereira TM, Branco FL, Braña AM, Filgueira-Júnior et al. (2015). Socioeconomic inequities and hepatitis A virus infection in Western Brazilian Amazonian children: Spatial distribution and associated factors. BMC Infect Dis, 15(1): 1-12. https:// doi.org/10.1186/s12879-015-1164-9.

Mock NB, Sellers TA, Abdoh AA, Franklin RR (1993). Socioeconomic, environmental, demographic and behavioral factors associated with occurrence of diarrhea in young children in the
Republic of Congo. Soc Sci Med, 36 (6): 807-816. https://doi.org/10.1016/0277-9536(93)90041-2.

Patil SR, Arnold BF, Salvatore AL, Briceno B, Ganguly S, Colford JM, Gertler PJ (2015). The effect of India's total sanitation campaign on defecation behaviors and child health in rural Madhya Pradesh: A cluster randomized controlled trial. PLoS Med, 11(8). https://doi: 10.1371/journal.pmed.1001709.

Pusat Data dan Informasi RI (2014). Situasi dan Analisis Hepatitis Tahun 2014.

Putri AG, Qadrijati I, Murti B (2020). Multilevel analysis: Villages do not have ecological effect on the risk of diabetes mellitus type 2 in Surakarta, Central Java. jepublichealth, 05(11): 106-118, https: //doi. org/10.26911/ jepublichealth.2020.05.01.11.

Ramadani AN, Rahardjo SS, Murti B (2019). The effects of social economic factors on diarrhea in Demak, Central Java. jepublichealth, 4(2): 88-96. https: //doi.org/10.26911/jepublichealth 2019.04.02.04.

Sabbahi S (2017). Specific excreted pathogens: environmental and epidemiology aspects: entamoeba histolytica. GWPP. Available at: http://www. waterpathogens.org.

Sari PH, Azhar K, Pradono J, Sukoco NEW (2018). Association of handwashing behavior, drinking water management and healthy homes with the occurrence of hepatitis in Indonesia. Jurnal Ekologi Kesehatan. 17(1): 4151.

https://www.researchgate.net/profile /Puti_Hidayangsih/publication/3284 94190_Association_of_Handwashing _Behavior_Drinking_Water_Manage ment_and_Healthy_Homes_with_th e_Occurrence_of_Hepatitis_In_Indo 
Retyono et al./ Village Does Not Have Contextual Effect on Hepatitis A Outbreak

nesia/links/5bd12a52299bf14eac8318 7a/Association-of-Handwashing-Behavior-Drinking-Water-Managementand-Healthy-Homes-with-the-Occurrence-of-Hepatitis-In-Indonesia.pdf

Viray MA, Hofmeister MG, Johnston DI, Krishnasamy VP, Nichols C, Foster MA, Balajadia R, Wise $\mathrm{ME}$ et al. (2019). Public health investigation and response to a hepatitis a outbreak from imported scallops consumed raw-Hawaii, 2016. Epidemiology and
Infection, 147. https://doi.org/10.1017/So950268818002844.

Zyl WB, Zhou NA, Wolfaardt M, Matsapola PN, Ngwana FB, Symonds EM, Fagnant-Sperati CS, et al. (2019). Detection of potentially pathogenic enteric viruses in environmental sam-ples from Kenya using the bagmediated filtration system. Water Sci Technol, 19(6): 1668-1676. https://doi.org/10.2166/ws.2019.046. 